\title{
COMPOUND-SPECIFIC RADIOCARBON ANALYSES OF PHOSPHOLIPID FATTY ACIDS AND $n$-ALKANES IN OCEAN SEDIMENTS
}

\author{
Ellen R M Druffel ${ }^{1} \bullet$ Dachun Zhang $・$ Xiaomei Xu $\bullet$ Lori A Ziolkowski $・$ John R Southon $・$ \\ Guaciara M dos Santos $\bullet$ Susan E Trumbore ${ }^{3}$ \\ Department of Earth System Science and Keck Carbon Cycle AMS Laboratory, University of California, Irvine, California \\ 92697-3100, USA.
}

\begin{abstract}
We report compound-specific radiocarbon analyses of organic matter in ocean sediments from the northeast Pacific Ocean. Chemical extractions and a preparative capillary gas chromatograph (PCGC) were used to isolate phospholipid fatty acids (PLFA) and $n$-alkanes from 3 cores collected off the coast of California, USA. Mass of samples for accelerator mass spectrometry (AMS) ${ }^{14} \mathrm{C}$ analysis ranged from $13-100 \mu \mathrm{g}$ C. PLFA extracted from anaerobic sediments in the Santa Barbara Basin (595 m depth) had modern $\Delta^{14} \mathrm{C}$ values $(-20$ to $+54 \%$ ), indicating bacterial utilization of surface-produced, post-bomb organic matter. Lower $\Delta^{14} \mathrm{C}$ values were obtained for $n$-alkanes and PLFA from coast ( $92 \mathrm{~m}$ depth) and continental slope $(1866 \mathrm{~m})$ sediments, which reflect sources of old organic matter and bioturbation. We present a brief analysis of the blank carbon introduced to samples during chemical processing and PCGC isolation.
\end{abstract}

\section{INTRODUCTION}

A preparative capillary gas chromatograph (PCGC) was set up at the Keck Carbon Cycle Accelerator Mass Spectrometry (AMS) laboratory in 2006, funded by a grant from the NSF Instrumentation and Facilities Division. Initially, phospholipid fatty acids (PLFA) were isolated from soil and leaf litter to study recent bacterial utilization of terrestrial organic matter (Kramer et al. 2010). The methods developed for the study of PLFA in soils and sediments were based on a previous study (Zelles 1999). Our goal was to isolate PLFA from marine sediments to study recent bacterial utilization of organic matter in the coastal California region. We also isolated odd $n$-alkanes from these sediments to study the timing of carbon fixation on land by higher plants and its transfer to the marine sediment reservoir. Sites from different depths and sedimentary regimes were studied, ranging from the shallow coast to the continental margin, and varying oxygen availability (anoxic to oxic).

Phospholipids are the primary lipids in membranes of living cells. They are labile and degrade within weeks after cell death, so the presence of PLFA indicate recent microbial heterotrophy. The carbon isotopic signature of PLFA has been used to determine the recent source of the carbon to bacteria. Using ${ }^{14} \mathrm{C}$ of microbial PLFA, Slater et al. (2006) found that there was significant depletion of $\Delta^{14} \mathrm{C}$ in saturated and mono-unsaturated PLFA indicating microbial incorporation of petroleum residues in a rocky intertidal zone contaminated by an oil spill in Nyes Neck, Massachusetts, USA. They concluded that molecular-level ${ }^{14} \mathrm{C}$ analyses of microbial PLFA are useful indicators of biodegradation of organic contaminants.

Long-chain $n$-alkanes are found in marine sediments and their abundances represent the relative amounts of terrestrial- versus marine-derived sources (Pearson and Eglinton 2000). There is a strong predominance of odd $n$-alkanes for leaf waxes of higher plants, whereas a strong predominance of even $n$-alkanes is found in petroleum, petroleum source rocks, and exposed continental rocks (Brassel and Eglinton 1980). Pearson and Eglinton (2000) used $\Delta^{14} \mathrm{C}$ and $\delta^{13} \mathrm{C}$ measurements of $n$-alkanes in Santa Monica Basin surface sediment and a 3-component mixing model to determine that terrestrial leaf waxes accounted for at least $80 \%$ of the $n$-alkanes in Santa Monica Basin sediments.

${ }^{1}$ Corresponding author. Email: edruffel@uci.edu.

${ }^{2}$ Current address: McMaster University, Hamilton, Ontario, Canada.

${ }^{3}$ Current address: Max-Planck Institute for Biogeochemistry, Jena, Germany.

(C) 2010 by the Arizona Board of Regents on behalf of the University of Arizona Proceedings of the 20th International Radiocarbon Conference, edited by A J T Jull RADIOCARBON, Vol 52, Nr 2-3, 2010, p 1215-1223 
We measured $\Delta^{14} \mathrm{C}$ of PLFA and long-chain $n$-alkanes in sediments from the Santa Barbara Basin, Santa Barbara coast, and continental slope sediments of the northeast Pacific (Figure 1). Previously, 2 of these cores were analyzed for organic fractions and bulk $\Delta^{14} \mathrm{C}$ (Hwang et al. 2005; Komada et al. 2005), and we compare our compound-specific $\Delta^{14} \mathrm{C}$ analyses to their results. Both studies concluded that these locations have different sedimentation rates and some are bioturbated by organisms (coast and slope), as well as receiving inputs of old organic matter from the Santa Clara drainage basin and resuspended sediments. These factors influence the range of $\Delta^{14} \mathrm{C}$ values of compounds reported here.

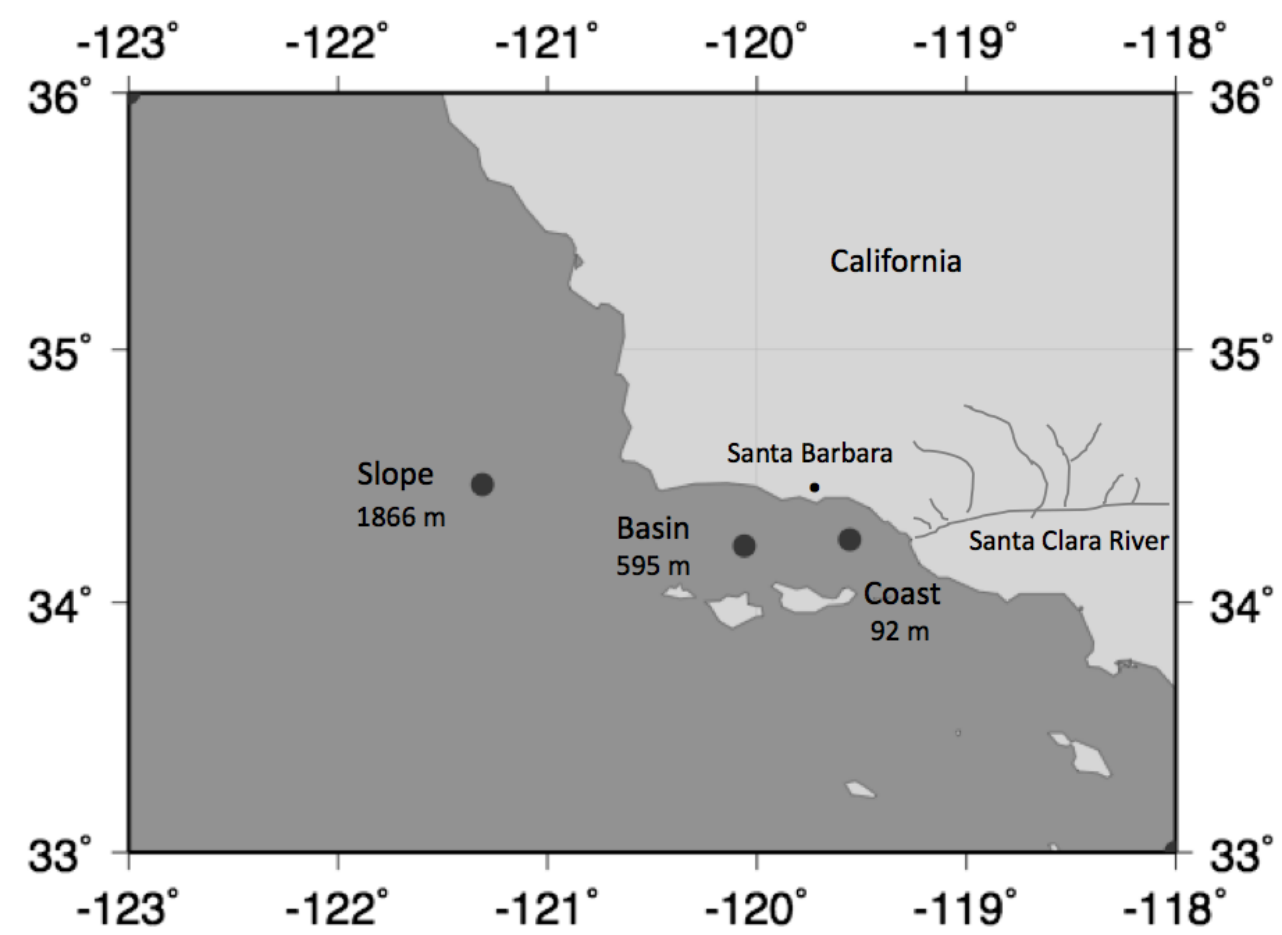

Figure 1 Map of the Southern California Bight region and the 3 locations where sediment samples were collected: coast ( $92 \mathrm{~m}$ water depth), basin (595 m water depth), and slope (1866 m water depth). Santa Clara River and the city of Santa Barbara are also indicated.

\section{SITES AND SAMPLING}

Three sites off the coast of central California were chosen for this study. The Santa Barbara Basin samples were collected in November 1996 (Pulse 32 cruise, R/V Revelle, Stn 3208) from the center of the basin $\left(34.225^{\circ} \mathrm{N}, 120.058^{\circ} \mathrm{W}\right)$ at $595 \mathrm{~m}$ water depth using an Ocean Instruments ${ }^{\circledR}$ Multicorer. Three horizons from a single core were taken for compound-specific radiocarbon analysis (CSRA) $(0-2,2-5,17-21 \mathrm{~cm})$. The Santa Barbara coast sediment was collected in June 2002 (Pulse 40 cruise, R/V New Horizon, Stn $4001 \mathrm{~b}, 34.250^{\circ} \mathrm{N}, 119.556^{\circ} \mathrm{W}$ ) at $92 \mathrm{~m}$ water depth using a grab sampler. The top $\sim 12 \mathrm{~cm}$ were taken as 1 sample for analysis. Sediment from the slope was collected in August 2001 (MULVFS cruise, R/V New Horizon, Stn \#3) from $1866 \mathrm{~m}$ water depth $\left(34.467^{\circ} \mathrm{N}\right.$, $\left.121.310^{\circ} \mathrm{W}\right)$ using a multicorer. Three horizons were taken for CSRA $(0.2-3.5,8-10,13-15 \mathrm{~cm})$ from a single core. After sectioning onboard, all sediment samples were frozen in cleaned glass jars at $-20{ }^{\circ} \mathrm{C}$. 


\section{EXTRACTION OF LIPIDS}

Extraction of freeze-dried, homogenized sediment was performed according to published techniques developed for soils (Zelles 1999). Briefly, 20-200 $\mathrm{g}$ of sediment was extracted with a mixture of $\mathrm{CHCl}_{3}$, methanol, and a phosphate buffer ( $\mathrm{pH}$ 7.4). The solution was passed through a SPE-Si gel column by eluting with chloroform, acetone, and methanol, to separate neutral, glyco-, and phospho-lipids, respectively. The neutral lipid fraction was extracted using urea adduction (Pearson and Eglinton 2000) to isolate the long-chain $n$-alkanes. The phospho-(polar) lipids were esterified with methanol and $\mathrm{KOH}$ to produce fatty acid methyl esters (FAMEs) and passed through a SPE- $\mathrm{NH}_{2}$ column to separate unsubstituted FAMEs. This mixture was passed through SPE-SCX to separate saturated PLFA and mono-unsaturated PLFA.

\section{PREPARATIVE CAPILLARY GAS CHROMATOGRAPHY (PCGC)}

Both $n$-alkanes and PLFA samples were collected and quantified on a Hewlett Packard 6890 GC equipped with an HP 7683B auto-injector, Gerstel cooled injection system (CIS-4) with split/splitless inlet, and a DB-XLB capillary column $(30 \mathrm{~m} \times 0.53 \mathrm{~mm}$ ID, $1.5-\mu \mathrm{m}$ film thickness or CP-Sil 8 CB Ultimetal column; $50 \mathrm{~m} \times 0.53 \mathrm{~mm}$ ID, $0.5-\mu \mathrm{m}$ film thickness). The volume of injected sample ranged from $1-3 \mu \mathrm{L}$ of the sample solution. A typical temperature program for separating PLFA on the $\mathrm{GC}$ column was $60{ }^{\circ} \mathrm{C}(1 \mathrm{~min}), 15^{\circ} \mathrm{C} / \mathrm{min}$ to $190{ }^{\circ} \mathrm{C}, 2{ }^{\circ} \mathrm{C} / \mathrm{min}$ to $230{ }^{\circ} \mathrm{C}(3 \mathrm{~min}), 20^{\circ} \mathrm{C} / \mathrm{min}$ to $320^{\circ} \mathrm{C}(2 \mathrm{~min})$. Helium was the carrier gas in the GC column. One percent of the flow from the end of the column was diverted to an FID (flame ionization detector) to confirm adequate separation and quantification of peaks. An example of the mono-unsaturated PLFA distribution is shown in Figure 2. The collection of individual lipids is done with a preparative fraction collector with a cooling system to isolate up to 6 individual compounds or groups of compounds from a sample in individual U-tube traps cooled to $-10^{\circ} \mathrm{C}$. Compound verification was performed using a Finnigan Trace $\mathrm{MS}+\mathrm{GC} / \mathrm{MS}$ operated in electron ionization mode. In general, 50 injections were made for each sample and all compounds were isolated at GC column temperatures at or below $280{ }^{\circ} \mathrm{C}$.

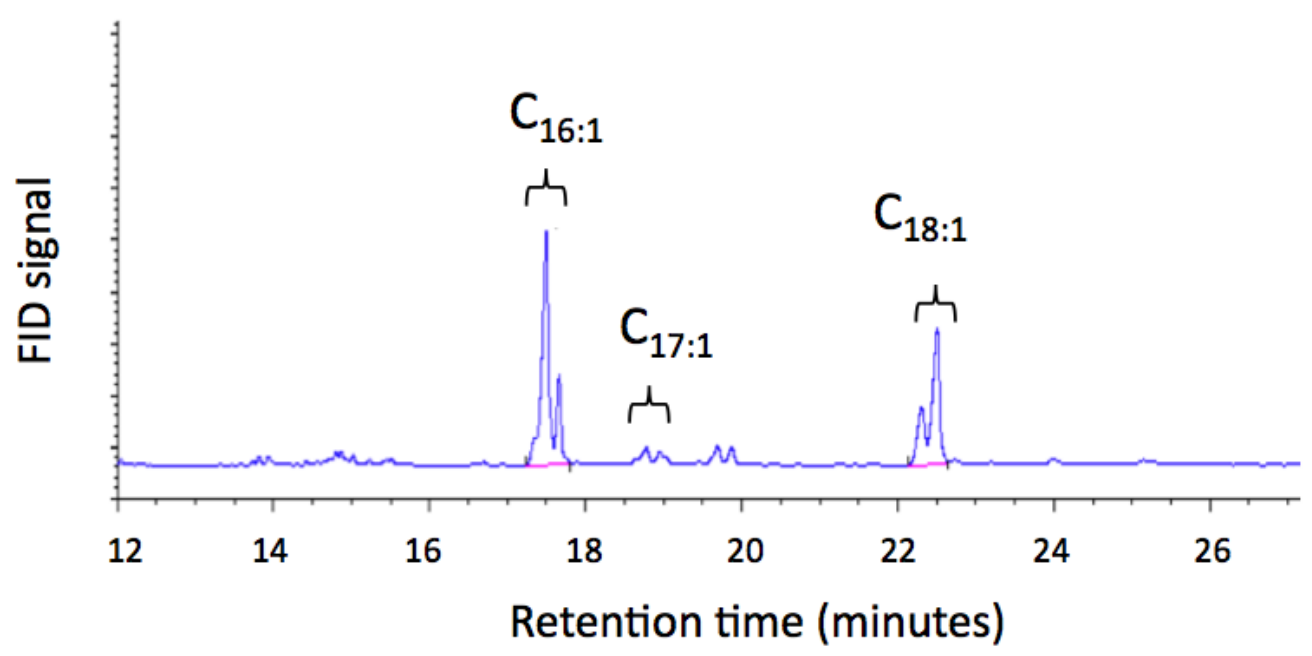

Figure 2 Mono-unsaturated PLFA distribution as observed by FID prior to PCGC collection for ${ }^{14} \mathrm{C}$ analysis from the $0-2 \mathrm{~cm}$ sample from the Santa Barbara Basin. 
Techniques have been developed for sample preparation, measurement setup, data analysis, and background corrections for accurately and precisely measuring samples containing a few microgram of carbon using a compact AMS system (NEC 0.5MV 1.5SDH-1) (Santos et al. 2007). At the KCCAMS facility, ultra-small samples $(\geq 0.002 \mathrm{mg} \mathrm{C}$ ) can be processed and measured with accuracy and precision of a few percent confirmed by a variety of ${ }^{14} \mathrm{C}$ standards. This is the result of high output beam currents from our modified NEC ion-source attached to the AMS spectrometer, coupled with the use of on-line AMS $\delta^{13} \mathrm{C}$ measurements (Santos et al. 2007, 2010). Given that some of the beam is from carbon introduced during sample preparation, proper background determination is a key factor that often limits overall accuracy of the analysis.

Compounds were transferred to quartz tubes, combusted to $\mathrm{CO}_{2}$, and reduced to graphite using hydrogen gas on iron powder for AMS analysis using the protocols for small samples (Santos et al. 2007). For determination of PLFA ${ }^{14} \mathrm{C}$, data from the FAMEs analyzed by AMS were corrected to remove the ${ }^{14} \mathrm{C}$-free $\mathrm{C}$ added in derivatization (Kramer and Gleixner 2008). No $\mathrm{C}$ was added in the $n$-alkane analyses. Radiocarbon results are reported as $\Delta{ }^{14} \mathrm{C}$ as specified for geochemical samples without known age (Stuiver and Polach 1977).

\section{RESULTS}

\section{Blank Carbon Determinations}

Rather than purify samples after collection on the PCGC, we directly quantified blank $\mathrm{C}$ in the following ways. The direct measurement of blank $\mathrm{C}$ from the PCGC was assessed with 150-300 injections of $\mathrm{CHCl}_{3}$ and a collection time of $10 \mathrm{~min}$. Blank C collected was $0.25 \pm 0.21 \mu \mathrm{g} \mathrm{C} / \mathrm{min}$ collection time/50 injections $(n=5)$. The PLFA and $n$-alkane samples were assessed for blank (nonsample) $\mathrm{C}$ using a modern methyl stearate standard for dead $\left({ }^{14} \mathrm{C}\right.$-free) blank $\mathrm{C}$ and a dead $\left({ }^{14} \mathrm{C}\right.$-free) $\mathrm{C}_{22}$ alkane for modern blank $\mathrm{C}$. The standards were dissolved in chloroform and passed through the PCGC, collected and analyzed for $\Delta^{14} \mathrm{C}$, which allowed us to calculate the mass of extraneous blank $\mathrm{C}$ present in our samples. The average dead blank $\mathrm{C}$ added to standards run over a 15 -month period was $0.42 \pm 0.07$ (sd) $\mu \mathrm{g} \mathrm{C} / \mathrm{min} / 50$ injections. An evaluation of the modern blank $\mathrm{C}$ was performed using a ${ }^{14} \mathrm{C}$-free $\mathrm{nC}_{22}$ alkane and yielded $0.09 \pm 0.04 \mu \mathrm{g} \mathrm{C} / \mathrm{min} / 50$ injections $(n=1)$, which is negligible in terms of corrected $\Delta^{14} \mathrm{C}$ values of individual samples. The blank $\mathrm{C}$ from chemical processing was assessed recently for the wet chemistry extraction of PLFA and PCGC steps and total blank mass ranged from 0.09 to $0.17 \mu \mathrm{g} \mathrm{C} / \mathrm{min} / 50$ injections, with a combined $\Delta^{14} \mathrm{C}$ value of $-635 \pm 21 \%$. The recent improvement of the blank $\mathrm{C}$ owes primarily to a new capillary column that we are not sharing with other users and no solvent transfer from the PCGC tube to the combustion tube.

Blank $\mathrm{C}$ was also assessed using samples of modern and ${ }^{14} \mathrm{C}$-free vanillin $\left(\mathrm{in}^{\mathrm{C}} \mathrm{CH}_{2} \mathrm{Cl}_{2}\right.$ ), which were passed through the PCGC, collected and analyzed for $\Delta^{14} \mathrm{C}$. The average mass of blank $\mathrm{C}$ added was $0.5 \pm 0.3 \mu \mathrm{g} \mathrm{C} / \mathrm{min} / 50$ injections $(n=10)$ (Ziolkowski and Druffel 2009). Chemical processing blank $\mathrm{C}$ for black carbon isolation was determined using small amounts of modern grass char and fossil hexane soot, standards that were used in the black carbon ring trial experiment (Hammes et al. 2007) following methods described elsewhere (Ziolkowski and Druffel 2009; Santos et al. 2010). Average mass of blank C added during chemical extraction and PCGC isolation was $1.1 \pm 0.7 \mu \mathrm{g} \mathrm{C} /$ $\min / 50$ injections $(n=13)$. Thus, about half of the blank $\mathrm{C}$ is from chemical processing, and half is from PCGC processing. The blank C contribution from the PCGC during PLFA and $n$-alkane isolations are similar to those obtained for black carbon isolations, even though they were collected at different retention times and column temperatures, indicating that below $280{ }^{\circ} \mathrm{C}$, column bleed did not affect the ${ }^{14} \mathrm{C}$ signatures of these isolated compounds differently. 


\section{Sediment $\boldsymbol{n}$-Alkane and PLFA Relative Abundances}

Distributions of $n$-alkanes in the coast and slope sediments are shown in Figure $3 \mathrm{a} . \mathrm{C}_{29}$ was the most abundant $n$-alkane in these sediments. An exception was the surface horizon of the slope core where $\mathrm{C}_{21}$ was slightly more abundant than $\mathrm{C}_{29}$. In general, $\mathrm{C}_{31}$ was the second most abundant $n$-alkane in the coast and slope sediments.

The distributions of PLFA in the basin and coast sediment samples are shown in Figure 3b,c. Of the 3 PLFA quantified, the most abundant saturated PLFA in the basin sediments was $\mathrm{C}_{16: 0}$, with less $\mathrm{C}_{15: 0}$ and even less $\mathrm{C}_{14: 0}$ (Figure $3 \mathrm{~b}$ ). Mono-unsaturated PLFA were predominantly $\mathrm{C}_{16: 1}$ in the basin sediments, with $\mathrm{C}_{18: 1}$ less abundant, in contrast to the coast sediment sample, which had slightly more $\mathrm{C}_{18: 1}$ than $\mathrm{C}_{16: 1}$.

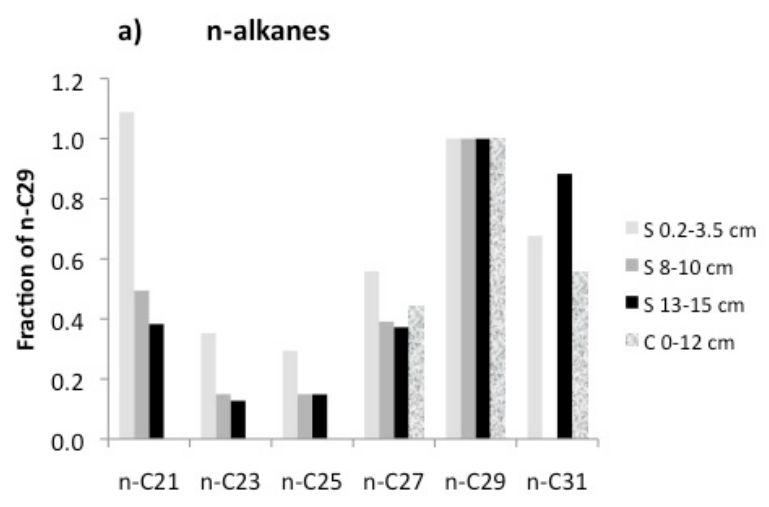

b) Saturated PLFA

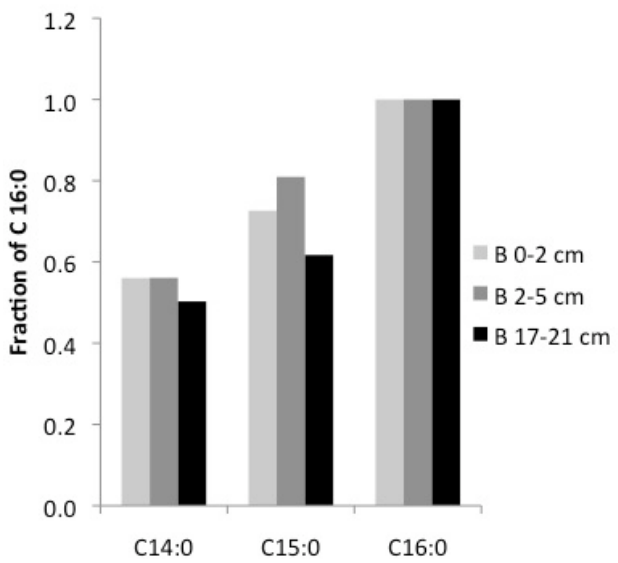

c) Monounsaturated PLFA

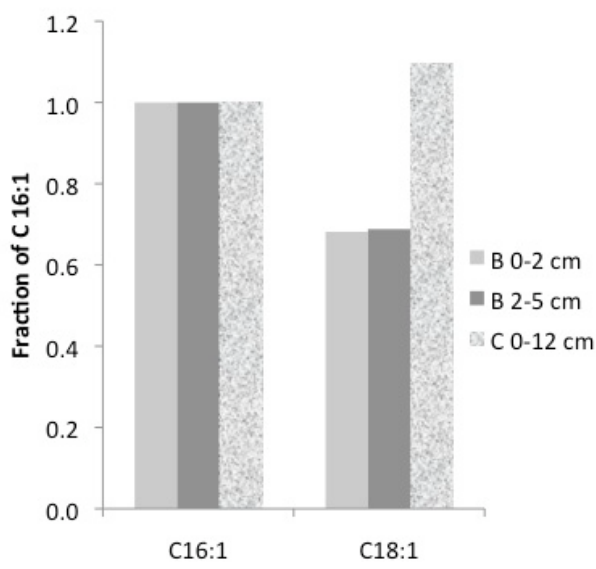

Figure 3 Abundance of a) $n$-alkanes relative to $n-\mathrm{C}_{29}$, b) saturated PLFA relative to $\mathrm{C}_{16: 0}$, and c) mono-unsaturated PLFA relative to $\mathrm{C}_{16: 1}$ in slope (S), basin (B) and coast (C) sediments.

\section{Sediment PLFA and $n$-Alkane $\Delta{ }^{14} \mathrm{C}$ Results}

$\Delta^{14} \mathrm{C}$ measurements of PLFA in the basin sediments ranged from $-99 \%$ (17-21 cm, $\mathrm{C}_{14: 0}, \mathrm{C}_{15: 0}$, and $\left.\mathrm{C}_{16: 0}\right)$ to $+54 \%$ o $\left(2-5 \mathrm{~cm}, \mathrm{C}_{16: 0}\right)$ (Figure 4 and Table 1). All samples of PLFA from the 2 upper horizons (0-2 and 2-5 cm) contained post-bomb carbon, or were greater than the pre-bomb surface water dissolved inorganic carbon value of $-70 \%$ (Berger et al. 1966) (Figure 4). Saturated PLFA in 
the upper 2 layers had higher $\Delta^{14} \mathrm{C}$ values $(+24$ to $+54 \%$ ) than those of the mono-unsaturated PLFA $(-20$ to $1 \%$ ). In the single horizon analyzed from coastal sediment $(0-12 \mathrm{~cm})$, the unsaturated PLFA $\left(\mathrm{C}_{16: 1}, \mathrm{C}_{18: 1}\right)$ had a pre-bomb value $(-174 \%)$. In the slope sediments, the pooled saturated and unsaturated PLFA from 3 horizons $(0.2-3.5,8-10,13-15 \mathrm{~cm})$ had lower $\Delta^{14} \mathrm{C}$ values $(-322,-357$, $-425 \%$, respectively) than those from the coast or basin sites (Figure 4, Table 1).

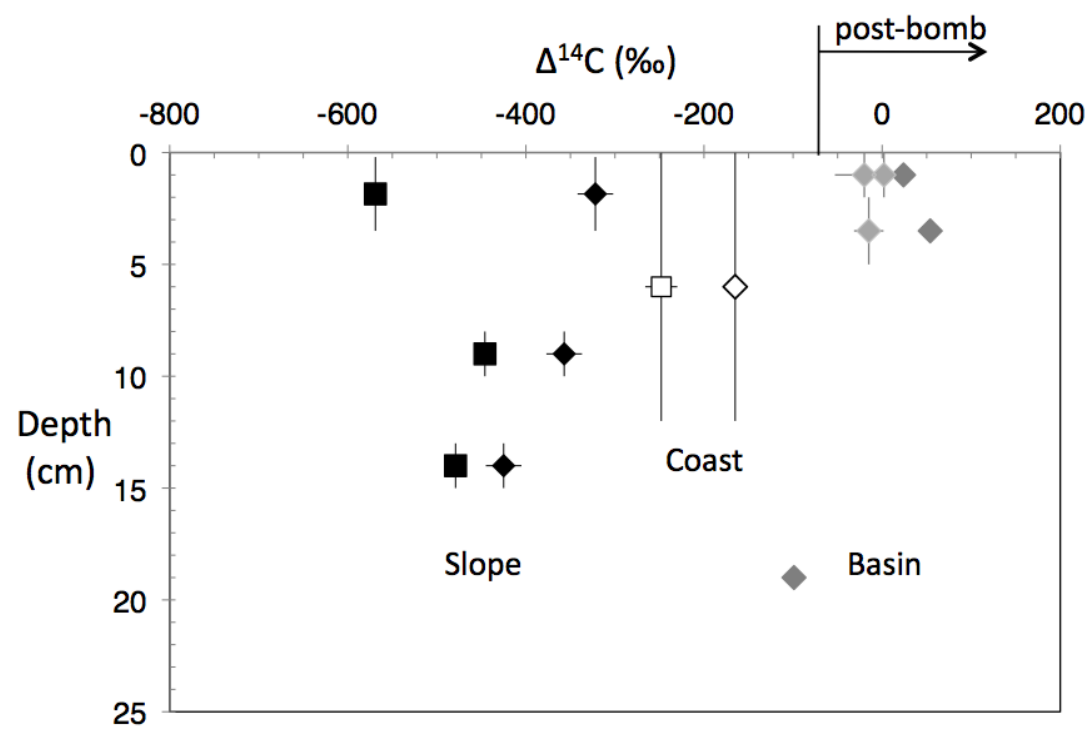

Figure $4 \Delta \Delta^{14} \mathrm{C}$ measurements of PLFA (diamonds) and $n$-alkane (squares) samples isolated from slope (black), coast (white) and basin (dark gray: saturated PLFA; light gray: mono-unsaturated PLFA) sediments. Individual compounds in each sample are listed in Table 1.

Table 1 Sample mass and $\Delta{ }^{14} \mathrm{C}$ values of compounds isolated from 3 sediment cores.

\begin{tabular}{|c|c|c|c|c|c|}
\hline $\begin{array}{l}\text { Depth } \\
\text { (cm) }\end{array}$ & UCIAMS nr & ID & $\mu \mathrm{g} \mathrm{C} \mathrm{C}^{\mathrm{a}}$ & $\begin{array}{l}\Delta^{14} \mathrm{C} \\
(\% 0)\end{array}$ & $\begin{array}{l} \pm \\
(\%)\end{array}$ \\
\hline \multicolumn{6}{|c|}{ Santa Barbara Basin (Pulse 32, $595 \mathrm{~m}$ depth) } \\
\hline $0-2$ & 47422 & PLFA C $_{16: 0}$ & 40 & 24 & 9 \\
\hline $0-2$ & 47423 & PLFA $C_{16: 1}$ & 15 & -20 & 22 \\
\hline $0-2$ & 47424 & PLFA C $\mathrm{C}_{18: 1}$ & 35 & 1 & 9 \\
\hline $2-5$ & 47425 & PLFA C $C_{16: 0}$ & 21 & 54 & 16 \\
\hline $2-5$ & 47426 & PLFA C $_{16: 1+18: 1}$ & 29 & -15 & 11 \\
\hline $17-21$ & 47427 & PLFA C $_{14: 0+15: 0+16: 0}$ & 13 & -99 & 24 \\
\hline \multicolumn{6}{|c|}{ Santa Barbara coast (Pulse 40, $92 \mathrm{~m}$ depth) } \\
\hline $0-12$ & 40219 & PLFA C $_{16: 1+18: 1}$ & 19 & -174 & 37 \\
\hline $0-12$ & 40220 & $n$-alkanes $C_{27+29+31}$ & 33 & -248 & 19 \\
\hline \multicolumn{6}{|c|}{ Slope (Mulvfs, $1866 \mathrm{~m}$ depth) } \\
\hline $0.2-3.5$ & 65623 & PLFA C $_{15: 0+16: 0+18: 0}+\mathrm{C}_{15: 1+16: 1+18: 1}$ & 100 & -322 & 20 \\
\hline $8-10$ & 65621 & 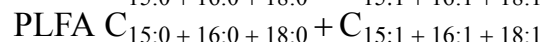 & 92 & -357 & 20 \\
\hline $13-15$ & 65622 & 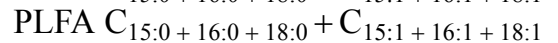 & 85 & -425 & 20 \\
\hline $0.2-3.5$ & 65626 & $n$-alkanes $\mathrm{C}_{21}+23+25+27+29+31$ & 96 & -569 & 10 \\
\hline $8-10$ & 65625 & $n$-alkanes $\mathrm{C}_{21}+23+25+27+29$ & 98 & -446 & 10 \\
\hline $13-15$ & 65624 & $n$-alkanes $\mathrm{C}_{21+23+25+27+29}$ & 65 & -479 & 10 \\
\hline
\end{tabular}

${ }^{\mathrm{a}} \mu \mathrm{g} \mathrm{C}$ is mass of carbon in sample. 
The $n$-alkane $\Delta^{14} \mathrm{C}$ results of sediments from the coast and slope sites were lower than the PLFA results obtained for these respective sites. Alkane $\Delta^{14} \mathrm{C}$ results in the slope sediments were lower overall $(-569 \%$ to $-446 \%)$ than that obtained in the coastal sediment $(-248 \%)$.

\section{DISCUSSION}

The $\Delta^{14} \mathrm{C}$ values of PLFA in the upper $5 \mathrm{~cm}$ of the basin core were all post-bomb $(>-70 \%)$, whereas those values in the coastal and slope sediments were pre-bomb. Because the sediments in the basin are anoxic, there is no bioturbation, and annual sediment laminations are preserved. Freshly deposited organic matter, mostly produced in the surface waters with $\Delta^{14} \mathrm{C}$ values of $20-60 \%$ (Druffel and Williams 1991), remains undisturbed on the surface since deposition. At a sedimentation rate of about 0.2-0.4 cm/yr (Kennett and Ingram 1995; Mollenhauer and Eglinton 2007), the upper $5 \mathrm{~cm}$ of these sediments were indeed deposited within the last $50 \mathrm{yr}$.

In contrast, sediment from the coast and slope sites are bioturbated in the upper few $\mathrm{cm}$ and the sedimentation rates (0.013-0.014 cm/yr, Hwang et al. 2005) are lower than that in the basin. Therefore, the $\Delta^{14} \mathrm{C}$ values of $n$-alkanes in these cores are lower, at least in part, due to mixing with older, deeper sediment.

Additionally, decay of ${ }^{14} \mathrm{C}$ accounts for a minor part of the ${ }^{14} \mathrm{C}$-depletion in the coast and slope sediment samples. With a sedimentation rate of $0.014 \mathrm{~cm} / \mathrm{yr}$ (Hwang et al. 2005), the age of sediments in the deepest slope horizon is $\sim 1000 \mathrm{yr}$; thus, age-corrected $\Delta^{14} \mathrm{C}$ of $n$-alkane and PLFA values in this horizon would be $-408 \%$ and $-347 \%$, respectively. Likewise, age-corrected ${ }^{14} \mathrm{C}$ values of $n$ alkane and PLFA analyses in the coast core are -206 and $-120 \%$, respectively. Thus, an old source of carbon at the time of deposition is required to explain the low $\Delta{ }^{14} \mathrm{C}$ values we find at the coast and slope sites.

Hwang et al. (2005) studied surface sediments along a transect from the Santa Clara River (a small mountainous river) to the deep northeastern Pacific that included the coast and slope sediments reported here. From $\Delta^{14} \mathrm{C}$ and $\delta^{13} \mathrm{C}$ measurements in bulk organic matter and organic compound fractions of surface sediment and a simple mixed layer model, they calculated that $\Delta^{14} \mathrm{C}$ values of source organic carbon to the coast and slope sediments was $-160 \pm 60 \%$ and $-180 \pm 20 \%$, significantly lower than plankton-derived carbon from the surface waters. The source of this old carbon is believed to be from laterally transported sedimentary organic carbon. Additionally, Komada et al. (2005) reported that fossil marine shale was eroded and transported from the Santa Clara River drainage basin and deposited to the coastal ocean. Therefore, the carbon deposited at our coast and slope sites was ${ }^{14} \mathrm{C}$-depleted initially, at the time of deposition.

Pearson and Eglinton (2000) reported $\Delta{ }^{14} \mathrm{C}$ values of the $n$-alkanes $\mathrm{C}_{27}, \mathrm{C}_{29}$, and $\mathrm{C}_{31}$ in surface sediments $(0-2.5 \mathrm{~cm})$ of the Santa Monica Basin, located $125 \mathrm{~km}$ east southeast of the Santa Barbara Basin site. They used a 3-component mixing model to represent the contributions of the different sources of $n$-alkanes to the sediments, petroleum, modern plant waxes and shale-derived alkanes, and calculated contributions of $12 \%, 80 \%$, and $8 \%$, respectively. Our $n$-alkane ${ }^{14} \mathrm{C}$ result for the coast sediment $(-248 \%)$ is sufficiently high that a plant wax source is reasonable. In contrast, the $n$ alkane $\Delta^{14} \mathrm{C}$ results for the slope sediment are much lower (-446 to $-569 \%$ ) and may reflect a higher relative contribution of ${ }^{14} \mathrm{C}$-depleted sources (e.g. petroleum and/or shale-derived alkanes) at the slope, or alternatively, could reflect mixing of older plant-derived alkanes by bioturbation. Without additional information, however, this remains unresolved. 
Low PLFA $\Delta{ }^{14} \mathrm{C}$ values in the coast and slope sediments is evidence of recent (within weeks) microbial utilization of old carbon, as shown previously in studies of ancient kerogen (Petsch et al. 2001) and petroleum (Slater et al. 2006), and in deeper horizons of soils (Kramer and Gleixner 2008). In the slope core, there is a substantial down-core change in the difference between PLFA and $n$-alkane $\Delta{ }^{14} \mathrm{C}$ values (Figure 4), where the difference is much larger in the surface horizon $(-247 \%$ ) than it is for the deeper horizons ( $-54 \%$ to $-89 \%$ ). This difference may have implications for the carbon source utilization of microbial communities at different core depths.

\section{SUMMARY}

The presence of PLFA in the 3 sediments indicates recent activity of heterotrophic bacteria (days to weeks). The carbon source for bacteria in the basin core was produced within the last few decades, likely in the surface ocean. The carbon source for bacteria in the coast and slope sediments had low $\Delta{ }^{14} \mathrm{C}$ values, and indicate that the microbes are utilizing older organic matter, likely contained within the acid insoluble fraction, similar to kerogen.

Additional compound-specific radiocarbon analyses are planned for these sediments, including black carbon, another likely component of the acid insoluble or kerogen-like fraction of sedimentary organic carbon along continental margins.

\section{ACKNOWLEDGMENTS}

Thanks to Christiane Kramer for her help developing the method for PLFA extraction, Sheila Griffin for lab support, and John Greaves for advice regarding GC-MS analyses. We thank Ken Smith and Jim Bishop for shared ship time. We are grateful to $\mathrm{Li} \mathrm{Xu}$ and an anonymous reviewer for their helpful comments on an earlier version of the manuscript. The NSF Instrumentation and Facilities Program (grant EAR-0447323) and the Keck CCAMS laboratory provided funding for this research.

\section{REFERENCES}

Berger R, Taylor R, Libby W. 1966. Radiocarbon content of marine shells from the California and Mexican West Coast. Science 153(3738):864-6.

Brassel S, Eglinton G. 1980. Environmental chemistry; an interdisciplinary subject; natural and pollutant organic compounds in contemporary aquatic environments. In: Albaiges J, editor. Analytical Techniques in Environmental Chemistry. Pergamon Series on Environmental Science. Oxford: Pergamon. p 1-22.

Druffel ERM, Williams PM. 1991. Radiocarbon in seawater and organisms from the Pacific coast of Baja, California. Radiocarbon 33(3):291-6.

Hammes K, Schmidt MWI, Smernik RJ, et al. 2007. Comparison of quantification methods to measure fire-derived (black/elemental) carbon in soils and sediments using reference materials from soil, water, sediment and the atmosphere. Global Biogeochemical Cycles 21: GB3016, doi:10.1029/2006GB002914.

Hwang J, Druffel E, Komada T. 2005. Transport of organic carbon from the California coast to the slope region: a study of $\Delta^{14} \mathrm{C}$ and $\Delta^{13} \mathrm{C}$ signatures of organic compound classes. Global Biogeochemical Cycles 19: GB2018, doi:10.1029/2004GB002422.

Kennett JP, Ingram BL. 1995. A 20,000-year record of ocean circulation and climate change from the Santa Barbara basin. Nature 377(6549):510-4.

Komada T, Druffel E, Hwang J. 2005. Sedimentary rocks as sources of ancient organic carbon to the ocean: an investigation through $\Delta^{14} \mathrm{C}$ and $\delta^{13} \mathrm{C}$ signatures of compound classes. Global Biogeochemical Cycles 19: GB2017, doi:10.1029/2004GB002347.

Kramer C, Gleixner G. 2008. Soil organic matter in soil depth profiles: distinct carbon preferences of microbial groups during carbon transformation. Soil Biology and Biochemistry 40(2):425-33.

Kramer C, Trumbore S, Fröberg M, Cisneros Dozal LM, Zhang D, Xu X, Santos GM, Hanson PJ. 2010. Recent ( $<4$ year old) leaf litter is not a major source of microbial carbon in a temperate forest mineral soil. Soil Biology and Biochemistry 42(7):1028-37.

Mollenhauer G, Eglinton T. 2007. Diagenetic and sedimentological controls on the composition of organic matter preserved in California Borderland Basin sediments. Limnology and Oceanography 52(2):558-76.

Pearson A, Eglinton T. 2000. The origin of $n$-alkanes in Santa Monica Basin surface sediment: a model based on compound-specific $\Delta^{14} \mathrm{C}$ and $\delta^{13} \mathrm{C}$ data. Organic Geochemistry 31(11):1103-16. 
Petsch S, Eglinton T, Edwards K. 2001. ${ }^{14} \mathrm{C}$-dead living biomass: evidence for microbial assimilation of ancient organic carbon during shale weathering. Science 292(5519):1127-9.

Santos G, Southon J, Griffin S, Beaupré S, Druffel E. 2007. Ultra small-mass ${ }^{14} \mathrm{C}$-AMS sample preparation and analyses at KCCAMS Facility. Nuclear Instruments and Methods in Physics Research B 259(1): 293-302.

Santos GM, Southon JR, Drenzek NJ, Ziolkowski LA, Druffel E, Xu X, Zhang D, Trumbore S, Eglinton TI, Hughen KA. 2010. Blank assessment for ultra-small radiocarbon samples: chemical extraction and separation versus AMS. Radiocarbon 52(2-3):1322-35.

Slater G, Nelson R, Kile B, Reddy C. 2006. Intrinsic bacterial biodegradation of petroleum contamination demonstrated in situ using natural abundance, molecular-level ${ }^{14} \mathrm{C}$ analysis. Organic Geochemistry 37(9): 981-9.

Stuiver M, Polach HA. 1977. Discussion: reporting of ${ }^{14} \mathrm{C}$ data. Radiocarbon 19(3):355-63.

Tissot B, Welte D. 1984. Petroleum Formation and Occurrence. New York: Springer-Verlag.

Zelles L. 1999. Fatty acid patterns of phospholipids and lipopolysaccharides in the characterisation of microbial communities in soil: a review. Biology and Fertility of Soils 29(2):111-29.

Ziolkowski LA, Druffel ERM. 2009. Quantification of extraneous carbon during compound specific radiocarbon analysis of black carbon. Analytical Chemistry 81(24):10,156-61. 